\title{
DETECTION OF CANINE DISTEMPER VIRUS USING NESTED PCR
}

\author{
Bavanilatha Muthiah and Parthiban M. \\ Shaleesha Stanley Elavarasu, Vinodh Stanley Stephan. \\ Department of Biotechnology Sathyabama University, Jeppiaar Nagar, Rajiv Gandhi Road, Chennai, India \\ E-mail : 'bavagold@gmail.com
}

\begin{abstract}
Canine Distemper Virus is one of the most contagious RNA virus, which causes many fatal respiratory problems in dogs, seals, Red foxes, lions, badgers etc.,. Detection of CDV poses a very big and important task among veterinarians. This report mainly emphasis on the isolation and detection of the canine distemper virus in a novel way. Nasal and ocular samples from 25 dogs were collected from the clinical ward. Out of that, the first 5 were cultured in cell lines, namely MDCK and VERO. These cultured samples were passaged each for about 7 times which was sufficient enough for PCR detection. Field samples and cultured samples were then processed. The Viral RNA was extracted from cultured samples and the corresponding cDNAs were synthesized. Finally RT-PCR was done and it was followed by nested PCR. Out of the 25 field samples tested, 2 of them were detected positive and out of the 5 cultured samples, 3 were detected positive. Thus, the sensitivity of detection is shown to increase by about $40 \%$ when cultured, as the RNA content is prone to increase in cell culture.ergillus niger, Surface culture, Banana peel, Biomass, Fermentation.
\end{abstract}

KEYWORDS: CDV,RT-PCR, nestedPCR.

\section{INTRODUCTION}

For many Years, CDV was the most feared viral disease-affecting dogs. CDV is a RNA virus which belongs to the morbillovirus genus and the family of paramyxoviridae. This will affect particularly 3 to 6 month age of dogs with high morbidity and mortality. CDV could survive for a longer period of time under cold condition ( $\mathrm{Ho}$ et al., 1979). CDV manifested by a diphasic fever curve \& acute rhinitis \& later by bronchitis, catarrhal pneumonia, severe gastroenteritis \& nervous signs (Winters, 1981).

Diagnosis of CDV was difficult in the case of dogs having some other diseases like Kennel cough in the early stage. Serological diagnosis might be accomplished through the detection of anti CDV IgM antibody (Blixenkrone-moller et al., 1991) but difficult to differentiate from vaccinated dogs. Then definite diagnosis could be made through isolation of virus by FAT staining but this takes several days to weeks and this is also successful for acute signs of distemper (Blixenkrone-moller et al., 1989, Fairchild et al., 1967). PCR developed followed by RTPCR, but detection of CDV with the RT-PCR was not satisfactory during the first and end stages of infection. Therefore in this study to find out the subclinical form of CDV infection, nested PCR was attempted. To avoid nonspecific amplification and also to confirm first step PCR product, nested PCR was done.

\section{MATERIALS AND METHODS}

\section{Collection of samples}

25 Dog samples which are clinically suspected and CDV were collected from clinical ward of Madras veterinary college. This reveals typical clinical signs of
CDV such as conjunctivitis, bronchitis, pneumonia, gastroenteritis and neurological manifestations.

\section{Preparation of Samples}

The samples both Nasal and Ocular and suspected positive field samples cases were taken, infected with MDCK and VERO cell line maintained in Dept of Animal Biotechnology, Madras Veterinary College, Chennai-7 passaged about 10 times and was used as a sample for PCR.

\section{Isolation of RNA}

Total RNA was prepared using acid Guanidium thiocyanate-Phenol-chloroform and Trizol extraction method. Cell culture adapted CDV strains such as Onderstepoort vaccine strain are able to replicate in many cell lines. MDCK and VERO were shown to be a good host for CDV isolation (Kai et al., 1993).

\section{Amplification of CDV Nucleocapsid (NP) gene}

Primers specific to Nucleocapsid (NP) gene of CDV Onderstepoort strain were used as follows

\section{P1: 5'-ATTTGGGAT TGCTTAGGA-3' \\ P2: 5'- GGCGCTCAT CTTGGACAT-3.}

In one step RT-PCR was carried out in a $29.5 \mu$ l reaction mixture containing Master mix for $\mathrm{CDNA}$ synthesis (1 reaction) first strand buffer $2.5 \mu \mathrm{l}$, Primer CDV1 $1 \mu \mathrm{l}$, Primer CDV2 $1 \mu \mathrm{l}$, dNTPs $1 \mu \mathrm{l}$, RT enzyme $1 \mu$, Nuclease free water $7 \mu$ land denatured RNA $12.5 \mu$ l was added and was incubated for 10 mins. at room temperature. Final synthesis was allowed to complete by incubating at $37^{\circ} \mathrm{C}$ in a water bath. The synthesizd CDNA was used as a 
template in $49 \mu \mathrm{l}$ of PCR reaction. The PCR reaction mixture consists of first strand buffer $2 \mu \mathrm{l}$, Taq complete mix $45 \mu \mathrm{l}$, Primer CDV1 $1 \mu \mathrm{l}$, Primer CDV2 $1 \mu \mathrm{l}$. PCR amplification of CDV was carried out in 30 sequential reaction cycles at $94^{\circ} \mathrm{C}$ for 30 secs, $54^{\circ} \mathrm{C}$ for 30 secs and $72^{\circ} \mathrm{C}$ for $1 \mathrm{~min}$. The $P C R$ product was stored in ice at $-20^{\circ} \mathrm{C}$

In Nested PCR, $2 \mu$ l of first strand buffer, Taq complete mix with their respective inner primers CDV-3 \& inner primer CDV4 were added. Amplified product was visualized under UV transilluminator after ethidium bromide staining.

\section{Analysis of PCR Product}

The PCR products were analyzed by $1.5 \%$ agarose gel electrophoresis and were sequenced. The homology nucleotide sequence of PCR product of local isolate is compared wit other isolates using BLASTAnalysis.

\section{Serological Tests}

\section{Agarose gel precipitation test (AGPT)}

An agarose gel is used as a matrix for combining diffusion with precipitation. The reactants diffuse through the gel towards each other and precipitation results when the equivalence points have been reached. A single antigen will give rise to a single line of precipitation in the presence of its homologous antibody. When two antigens are present in a system, each behaves independently of the other.

Serum antibodies are not homogeneous. It is difficult to obtain a single antigen even in the purest preparations, so there are several antigen-antibody reactions possible in a single mixture. Gel diffusion permits the examination of such multiple systems since the technique allows the separation of the reactions. The individual components in a system react independently of each other so precipitation tests in agar are termed double immunodiffusion tests or simply immunodiffusion. The hazy white background of the solid agar matrix allows visualization of the precipitation reaction.

\section{DOT-ELISA}

In the dot ELISA, the antigen is held between two antibodies which react with two different epitopes on the same antigen. The antigen is to be immobilized onto a solid support strip. The primary antibody was added followed by the addition of secondary antibody (secondary antibody) conjugated to enzyme (Horse radish peroxidase).

The amount of enzyme linked antibody bound is assayed by incubating strip with an approximate chromogenic substrate $\left(\mathrm{H}_{2} \mathrm{O}_{2}, \mathrm{TMB}\right)$ which is then converted into a coloured insoluble product. The later precipitates onto a strip in area of enzyme activity and hence named as DOT ELISA. The enzyme activity is indicated by intensity of spot, which is directly proportional to antigen concentration.

$2 \mu \mathrm{l}$ of antigen in test sample was impregnated onto the nitrocellulose membrane and it was allowed to dry for 2 mins. The primary antibody (1:1000) was added and incubated at $37^{\circ} \mathrm{C}$ for 30 mins. Then secondary antibody $(1: 1000)$ conjugated to enzyme was added and incubated at $37^{\circ} \mathrm{C}$ for 30 mins. The excess unbound antibodies were washed with tap water and the colored dots were observed

\section{RESULTS AND DISCUSSION}

\section{Virus isolation in cell culture:}

MDCK infected by CDV showed typical viral infection signs such as clumping of cells at the margin, rounding of the otherwise polyangular cells along with the appearance of inclusion bodies which was less pronounced in CDV infected VERO cells. These observations concur with the prominent cytopathic effects reported in MDCK compared to VERO by Lednicky et al., 2004. About 7 passages in each cell lines were adequate for molecular detection.

\section{NP gene}

The nucleoplasmid gene, being one of the better host protected genes was selected for PCR amplifications. NP gene can accommodate certain changes in sequences which allow a higher degree of persistence and virulence. The improved persistence facilitated the culturing of CDV onto MDCK and VERO cell line, whereas the improved viral virulence helped in better molecular detection. Primers specific for NP gene of the Onderstepoort strain of CDV were used.

\section{NESTED PCR combined with RT PCR}

Positive results were obtained in a higher percentage when nested PCR was combined with RTPCR, when compared to RT-PCR alone. Nested PCR showed $60 \%$ positive results for cultured field samples while only $20 \%$ of the field samples were detected positive. The sensitivity of RT-PCR alone was inadequate enough to detect viral RNA. This work co related with the superiority of nested PCR as a RNA detection tool by Rzezutka et al., 2002 and falls in line to the higher sensitivity of detection as stated as Yong-Hwan Kim et al., 2001. Non-specific reactions were common in conventional antigen detection methods such as AGPT and DOT-ELISA. Hence more samples were found positive in conventional methods than Nucleic acid based method viz., PCR. PCR is based on genome of the virus, 
which gives accurate diagnosis of CDV infections. The product obtained by the nested PCR was found to be about between $400 \mathrm{bp}$ to $500 \mathrm{bp}$ which was in accordance to the band of 418bp obtained by Yong-Hwan Kim et al., 2001, confirming the product.

We conclude that culturing of the CDV samples in the two cell lines (MDCK and VERO) increased the RNA content which enabled a $40 \%$ increase in the sensitivity of nested PCR. The probability of detecting the virus is greater after culturing the viral samples, which makes up for the time consuming aspect of this technique. Research on easier adaptation of the virus to culture and identification of better cell lines would make this technique get closer to be a confirmatory test for CDV detection.

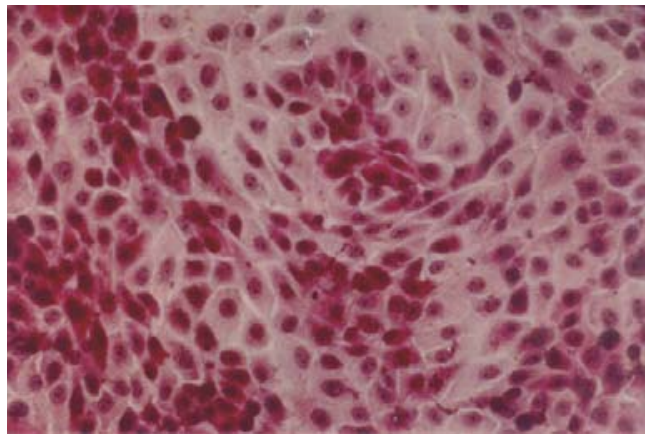

Fig .1 Normal MDCK cells before CDV infection

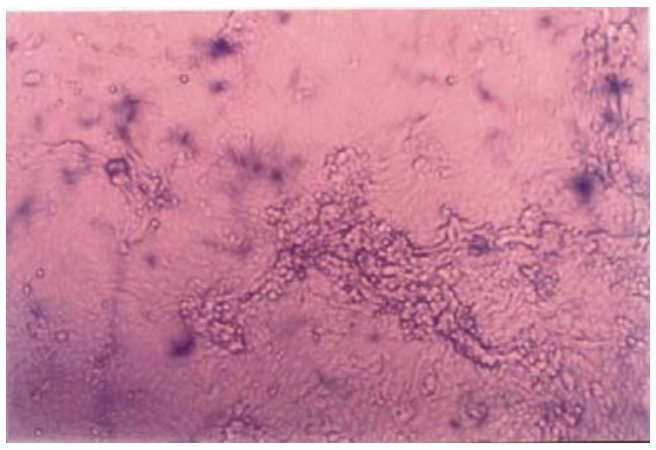

Fig .2 MDCK cells infected with CDV

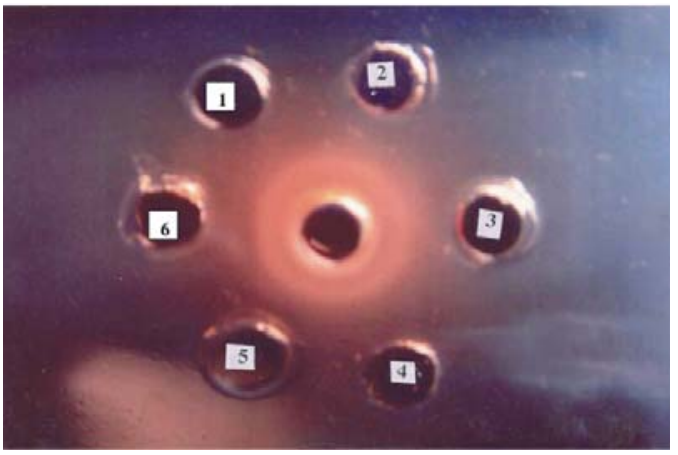

Fig .3 Agar gel precipitation test slide
Positive cases:

1. Case No: 117938

2. Case No: 125899

3. Case No: 116173

4. Case No: 116210

5. Case No: 116601

6. Positive Control

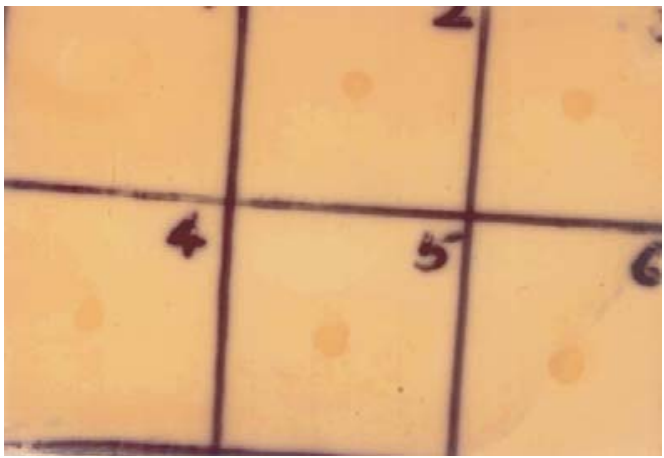

Fig .4 Dot-ELISA (Coloured spots on Nitrocellulose membrane)

1. Negative control

2. Case No: 117938

3. Case No: 125899

4. Case No: 116173

5. Case No 116210

6. Case No: 116601

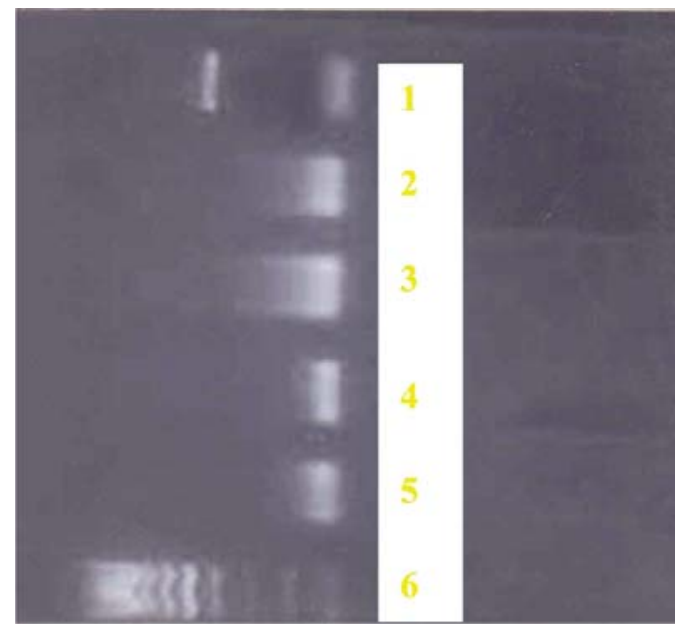

Fig .5 Gel showing one field positive sample

1. Case No: 11938

2. Case No: 116601

3. Case No: 117889

4. Case No: 118619

5. Case No: 118146

6. $1 \mathrm{~kb}$ molecular weight marker 


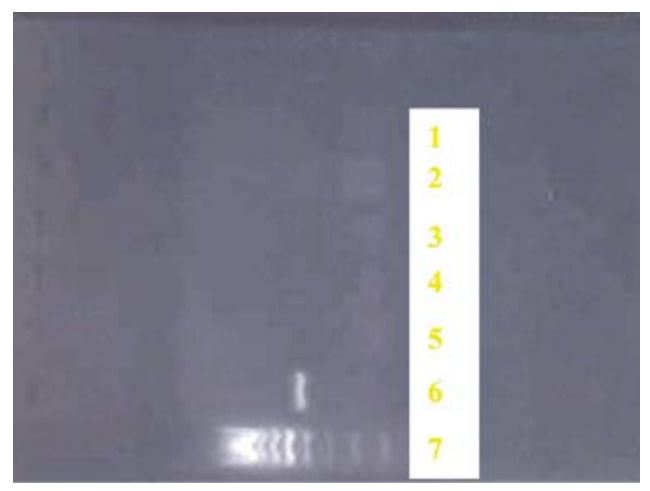

Fig .6 Gel showing one field sample positive

1. Case No: 121030

2. Case No: 121196

3. Case No: 123040

4. Case No: 123998

5. Case No: 125107

6. Case No: 126871

7. Case No: 125899

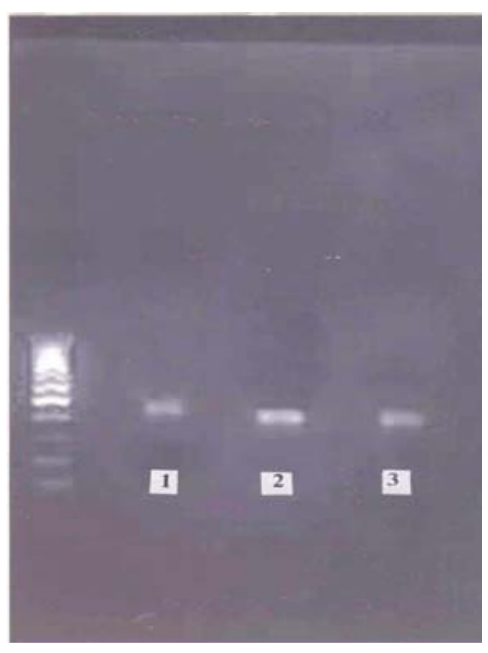

Fig $.7 \mathrm{Gel}$ showing three positive cultured samples

1. Case No: 116173 (MDCK)

2. Case No: 116601 (VERO)

3. Case No: 116210 (MDCK)
Table-1. Comparison of antigen detection methods with molecular techniques

\begin{tabular}{|c|c|c|c|c|c|}
\hline S. No. & $\begin{array}{c}\text { Animal } \\
\text { Case No. }\end{array}$ & Breed & AGPT & DOT-ELISA & $\begin{array}{l}\text { RT.PCR cembined } \\
\text { with Nested PCR }\end{array}$ \\
\hline 1. & 116173 & Non-describable & + & + & + \\
\hline 2. & 116210 & Non-describable & + & + & + \\
\hline 3. & 116295 & Non-describable & . & $\cdot$ & $\cdot$ \\
\hline 4. & 116539 & Non-describable & . & . & - \\
\hline 5. & 116601 & Non-describable & + & + & + \\
\hline 6. & 117889 & Non-describable & - & - & - \\
\hline 7. & 117938 & Non-describable & + & + & + \\
\hline 8. & 118146 & Non-describable & . & . & . \\
\hline 9. & 118376 & Non-describable & - & $\cdot$ & - \\
\hline 10. & 118619 & Labrador & . & - & - \\
\hline 11. & 118376 & Non-describable & . & - & - \\
\hline 12. & 117934 & Non-describable & . & . & . \\
\hline 13. & 118146 & Non-describable & - & - & . \\
\hline 14. & 119347 & Non-describable & $\cdot$ & $\cdot$ & $\cdot$ \\
\hline 15. & 119389 & Non-describable & $\cdot$ & $\cdot$ & $\cdot$ \\
\hline 16. & 119238 & Non-describable & $\cdot$ & $\cdot$ & $\cdot$ \\
\hline 17. & 119406 & Non-describable & $\cdot$ & $\cdot$ & - \\
\hline 18. & 121030 & Non-describable & $\cdot$ & $\cdot$ & - \\
\hline 19. & 121196 & Non-describable & $\cdot$ & $\cdot$ & $\cdot$ \\
\hline 20. & 123040 & Non-describable & $\cdot$ & $\cdot$ & $\cdot$ \\
\hline 21. & 123998 & Non-describable & . & $\cdot$ & . \\
\hline 22. & 125107 & Non-describable & . & $\cdot$ & . \\
\hline 23. & 125899 & Non-describable & + & + & + \\
\hline 24. & 126871 & Non-describable & $\cdot$ & $\cdot$ & $\cdot$ \\
\hline 25. & 126950 & Labrador & . & - & - \\
\hline
\end{tabular}

\section{REFERENCES}

[1] M. Blixenkrone-Moller, Pedersen, J.R., Appel, M.J. and Griot C. 1991, Detection of IgM antibodies against canine distemper virus in dogs and mink sera employing enzyme linked immunosorbent assay (ELISA). J. Vet.Diag.Invest., 3, 3-9.

[2] M.Blixenkrone-Moller 1989, Detection of intracellular canine distemper virus antigen in mink inoculated with an attenuated or a virulent strain of canine distemper virus .Am.J.Vet.Res. 50, 16161620.

[3] G.A. Fairchild, Wysman, M.and Donovan, E.F 1967, Flourescent antibody technique as a diagnostic test for canine distemper virus infection: detection of viral antigen in epithelial tissues of experimentally infected dogs.Am.J.Vet.Res., 28, 761-768.

[4] J.S. Guy, 1986, Diagnosis of canine viral infections. Vet.Clin.Nor.Ame small AniPrac. 16,1145-1156

[5] C.K. Ho, and Bahiuk, L.A 1979, Anew plague system for canine distemper characteristics of the green strain of canine distempervirus. Can.J.Microbiol, 25, 680-685.

[6] A. Rzezutka, Mizak B. 2002. "Application of N-PCR for diagnosis of distemper in dogs and fur animals". Vet Microbiol; 88(1): 95-103 
[7] W.D.Winters 1981, Time dependent decreases of maternal canine virus antibodies in newborn pups. Vet. Rec., 108, 295-299.

[8] Yong-Hwan Kim, Kyu-Woan Cho1, Hwa-Young Youn, Han Sang Yoo and Hong-Ryul Han. 2001, "Detection of canine distemper virus (CDV) through one step RT-PCR combined with nested PCR". J. Vet. Sci., 2(1), pp59-63

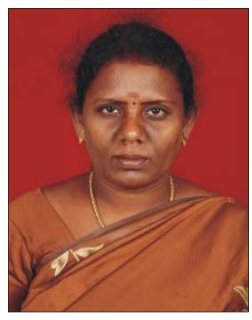

Ms. Bhavani Latha Muthiah is presently working as a lecturer in Department of Biotechnology Sathyabama University, Chennai. She has five years of teaching experience and pursuing research in the field of Recombinant DNA Technology and Animal Biotechnology. 